\title{
Pemahaman Imam Al-Qurthubi Terhadap Konsep Riddah dalam Al-Qur'an dan Relevansinya dengan Indonesia
}

\author{
Rumni Hafizah *) \\ Perguruan Diniyah Puteri \\ Padang Panjang, Sumatera \\ Barat, Indonesia \\ E-mail: \\ rumni_hafizhah@yahoo.com
}

\section{Risman Bustamam}

Institut Agama Islam Negeri Batusangkar, Sumatera Barat, Indonesia

E-mail:

rismanbustamam@yahoo.com

\begin{abstract}
Abstrak: Riddah merupakan suatu tindakan kriminal dan memiliki dampak yang besar dalam Islam. Konsep riddah di dalam al-Qur'an tidak dijelaskan secara rinci, sehingga diperlukannya suatu penafsiran agar bisa dipahami dengan jelas. Tujuan penelitian ini adalah untuk mengkaji, bagaimana ketentuan riddah dalam ayat-ayat al-Qur'an menurut penafsiran al-Qurtubi. Maka tujuan penelitian ini selengkapnya adalah untuk mendeskripsikan dan menganalisa; (1) makna riddah (2) penyebab riddah (3) hukuman bagi orang murtad (4) relevansi riddah dalam penafsiran al-Qurthubi dengan zaman sekarang. Untuk mencapai tujuan di atas, penelitian ini menggunakan kepustakaan. Metode analisis yang digunakan adalah metode tafsir tematik. Hasil penelitian ini bahwa menurut al-Qurthubi: 1) Makna riddah adalah keluar dari Islam dan kembali menjadi kafir, 2) Sebab riddah meliputi dengki, saling berteman dan bergaul dengan orang kafir, (3) Hukuman bagi orang murtad adalah dibunuh, terhapus amalan di dunia dan di akhirat (4) Relevansi penafsiran al-Qurthubi dengan zaman sekarang cukup urgen, namun segi hukuman bunuh terhadap orang murtad terlihat bertentangan. Di Indonesia hukuman bunuh tidak bisa diterapkan, karena hak asasi manusia (HAM) selalu dijadikan sebagai rujukan kebebasan dalam berpindah agama.
\end{abstract}

\begin{abstract}
Riddah is a criminal act and has a huge impact in Islam. The concept of riddah in the Qur'an is not explained in detail, so the need for an interpretation to be understood clearly. The purpose of this study is to examine, how the provisions of riddah in the verses of the Qur'an according to the interpretation of al-Qurtubi. So the purpose of this research is completely to describe and analyze; (1) the meaning of riddah (2) the cause of riddah (3) punishment for apostates (4) the relevance of riddah in the interpretation of al-Qurthubi with the present. To achieve the above objectives, this study uses the literature. The method of analysis used is the thematic interpretation method. The results of this study that according to al-Qurthubi: 1) The meaning of riddah is to leave Islam and return to infidelity, 2) Because riddah includes envy, mutual friends and association with infidels, (3) The punishment for apostates is to be killed, erased practices in world and in the hereafter (4) The relevance of al-Qurthubi's interpretation with the present is quite urgent, but in terms of the death penalty for apostates is seen to be contradictory. In Indonesia, the death penalty cannot be applied, because human rights (HAM) have always been used as a reference for freedom to convert.
\end{abstract}

Kata Kunci: Al-Qurthubi, riddah, tafsir

*) Corresponding Author manusia untuk memperoleh kebahagian

Islam adalah agama yang diridhoi baik di dunia maupun di akhirat. Islam oleh Allah SWT, yang membimbing menjadi salah satu nikmat Allah yang 
amat besar kepada umat manusia. pemeliharaan agama, karena identitas Sebagai hukum yang berlaku untuk yang membedakan seseorang sebagai segala zaman dan tempat, maka hukum muslim atau kafir adalah apakah ia Islam itu sifatnya umum. Artinya sifat meyakini dan beriman atau tidak dan perundangannya itu ditujukan terhadap ajaran agama Islam, justru itu secara keseluruhan tidak pada Islam melarang perbuatan murtad atau perorangan saja melainkan untuk riddah(Rodin, 2014: 254).

semua hal, semua orang, dan semua

Dalam fiqih Islam, riddah masyarakat. Pada prinsipnya setiap dikategorikan sebagai jarimah hudud, penetapan hukum itu haruslah yaitu suatu tindakan kejahatan yang memperhatikan kepentingan sanksi hukumnya didasarkan atas nas, masyarakat, dengan memelihara tujuan atau penetapan hukumnya tidak syara', menarik kebaikan dan menolak didasarkan atas kebijakan pemerintah. segala kerusakan atau mufasadah Tujuan pemberian sanksi atas pelaku (Abdurrahman, 1996: 71).

riddah, supaya seseorang tidak mudah

Memeluk Islam merupakan fitrah bagi manusia dengan rasa tanggung melakukan perbuatan jarimah dan demi terwujudnya kemaslahaan umat. jawab untuk memelihara dan Kemaslahatan dimaksud adalah mempertahankannya tanpa adanya perlindungan terhadap agama, jiwa, suatu paksaan. Untuk itu seluruh keturunan, akal dan harta benda. tatanan ajaran agama yang ditetapkan Dengan kata lain, pemberian sanksi Islam, baik yang berkaitan dengan atas pelaku riddah sebagai realisasi aqidah, syariat maupun akhlak, atas hifz al-din (perlindungan terhadap bertumpu pada lima tujuan utama yang agama). Islam memberikan kebebasan sangat mendasar, yaitu memelihara kepada masing-masing individu, dan keyakinan agama, keamanan dan Islam sebagai agama tidak memaksa, keselamatan jiwa, akal, keturunan dan untuk dipeluk oleh siapapun. Dari sini harta. Dari kelima tujuan dasar kemudian memunculkan kegelisahan tersebut, memelihara agama merupakan ketika melihat konsep riddah yang tujuan yang tertinggi tingkatannya. selalu menjadi ancaman besar untuk Islam sangat mementingkan mereka yang "keluar" dari agama Islam 
ke agama lain (Nada, 2004: 5). Agama dalam pemikiran muslim kontemporer liberal merupakan suatu hak privat yang melekat pada setiap orang. Dengan perkataan lain, setiap manusia bebas dan merdeka untuk memilih atau keluar dari suatu agama (Muqshit, 2013: 283).

Hal ini sebagaimana firman Allah menjelaskan:

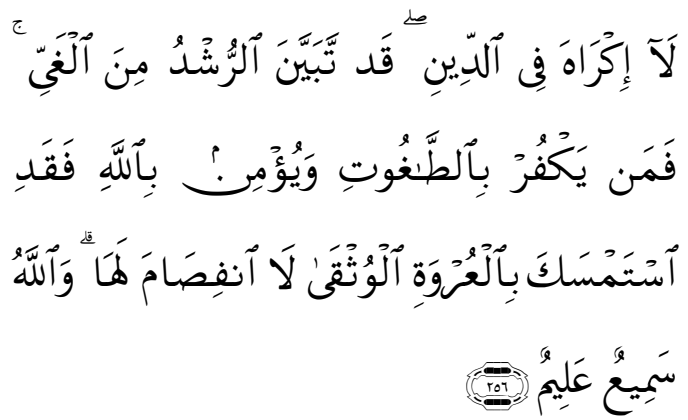

"Tidak ada paksaan untuk (memasuki) agama (Islam); Sesungguhnya telah jelas jalan yang benar dari pada jalan yang sesat. karena itu Barangsiapa yang ingkar kepada Thaghut dan beriman kepada Allah, Maka Sesungguhnya ia telah berpegang kepada buhul tali yang Amat kuat yang tidak akan putus. dan All ah Maha mendengar lagi Maha mengetahui. (QS al-baqarah: 256)

Dengan merujuk pada penafsiran ayat la ikraha fiddin, maka setiap orang bebas untuk memeluk agama. Jadi seseorang tidak boleh dipaksa untuk memeluk suatu agama, termasuk untuk memeluk Islam. Para pemikir Islam progresif liberal berpendapat bahwa sebagaimana bebas untuk memeluk suatu agama, maka seharusnya bebas juga untuk keluar dari suatu agama. Pemikiran seperti ini memberi otonomi penuh kepada manusia untuk memilih atau keluar dari suatu agama (Muqshit, 2013: 284).

Pandangan demikian berbeda dengan konsep fiqih klasik, karena orang yang keluar dari agama Islam (murtad) itu dianggap pelaku kriminal. Zayn al-Din al-Malibari, seperti dikutip Dimyati meletakkan pembahasan murtad setelah membahas soal jinayah (pidana), karena riddah menjadi bagian dari tindakan kriminal. Bedanya, sekiranya membunuh orang merupakan tindakan kriminal terkait pidana atas jiwa (jinayah bi al-nafs), maka riddah adalah jinayah terkait agama (jinayah bi al-din). Begitu juga berbeda dengan pelaku kriminal biasa, ketika orang murtad meninggal dunia, menurut Shata al-Dimyati, tidak perlu dimandikan, dikafani, disalatkan, dan tidak boleh dikuburkan di pekuburan umat Islam (al-Dimyati, juz IV:132). Sedangkan menurut ulama Mutaakhirin, orang murtad tidak dibunuh kecuali jika memerangi Islam atau mengajak manusia lain kepada murtad (Zaharuddin, 2010 :80). 
Di dalam al-Qur'an dan hadis Sedangkan untuk menganalisa konsep riddah memang tidak penafsiran ayat-ayat riddah dijelaskan secara rinci, namun fiqhlah menggunakan pendekatan tafsir, memberi pengertian, kriteria, dan content analisis, dan hermeneutik tafsir. batas-batas murtad. Bahkan pengertian Sumber data primer dalam penelitian murtad dalam fikih demikian luas, ini adalah ayat-ayat al-Quran yang sehingga orang-orang yang tidak berkaitan dengan riddah, yang dikaji merespons ketika azan pada kitab tafsir Jami' li Ahkamil dikumandangkan dan tidak Qur'an karangan al-Qurthubi. Sumber mendengarkan tatkala al-Quran data sekunder dalam penelitian ini dibacakan bisa digolongkan sebagai berupa buku-buku, jurnal-jurnal, dan murtad. Zayn al-Din al-Malibari, artikel yang berhubungan dengan sebagaimana dielaborasi Shata al- riddah.

Dimyati dalam I'anat al-Talibin, berkata bahwa kemurtadan tidak hanya disebabkan oleh pengingkaran seseorang terhadap kemukjizatan alQur'an melainkan juga penolakannya pada satu huruf al-Qur'an (Muqshit, 2013: 290).

\section{METODE PENELITIAN}

Penelitian ini menggunakan kepustakaan. Metode analisis yang digunakan adalah metode tafsir tematik/maudhu'i. Untuk meneliti kajian al-Qur'an penulis menggunakan metode tafsir mawdhu'i, dan teknik pengumpulan ayatnya menggunakan al-Mu'jam al-Mufahras li Alfazh alQur'an al-Karim melalui kata kunci دّ. lain. Ayat-ayat ini secara redaksional

\section{HASIL DAN PEMBAHASAN}

Riddah (Murtad) dalam Islam Ayat-Ayat Tentang Riddah Dalam AlQur'an

Riddah berasal dari akar kata رد yang berarti kembali atau berpaling dari sesuatu kepada yang lain. Secara terminologi riddah adalah meninggalkan keimanan dan kembali kepada kekufuran. Di dalam al-Qur'an riddah yang berasal dari akar kata رد terdapat 57 ayat dalam 30 surat.

Selain menggunakan kata riddah, كَفَرُوْ ا

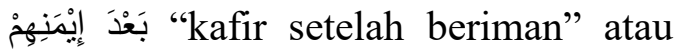
perpindahan agama Islam ke agama 
tidak menggunakan term murtad, tetapi secara subtansial menunjukkan makna murtad. Hal ini dijelaskan pada ayat: QS. Ali 'Imran: 86, 90, dan 106, QS. al-Nisa': 137, QS. al-Maidah: 5 dan 12, QS. al-Naḥl: 106, dan QS. an-Nur: 55.

\section{Makna Riddah}

Riddah secara etimologis berasal dari akar kata (ارتدّ) irtadda dari kata

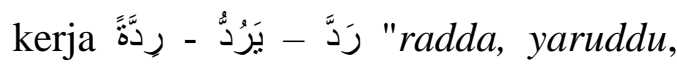
riddah, yang berarti (صرفه) "șarafahu", yaitu mengalihkan dan (أرجعه) "arja'ahu" yaitu mengembalikan (alMunawwir, 1995: 522).

Arti riddah secara bahasa yaitu kembalinya seorang Muslim yang akil baligh, dari agama Islam kepada bentuk kafir tanpa ada paksaan dari manapun. Sedangkan secara istilah yang populer digunakan para ulama, riddah dimaknai meninggalkan keimanan dan kembali pada kekufuran. Al-Sayyid al-Sabiq menjelaskan lebih rinci bahwa riddah adalah kembalinya orang Islam yang berakal dan dewasa pada kekafiran dengan kehendaknya sendiri tanpa ada paksaan dari orang lain, baik ia laki-laki atau pun perempuan (al-Sabiq, 1983: 381). Menurut Abdul Qadir Audah riddah adalah:

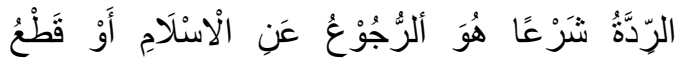

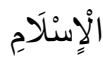

Riddah adalah kembali (keluar) dari agama Islam atau memutuskan (keluar) dari agama Islam (Audah, Juz II: 706).

Menurut Fathul Qadir orang murtad adalah orang yang keluar meninggalkan Islam berpindah kepada kafir. Riddah juga diartikan sebagai orang yang mengingkari wujud Sang Pencipta, menafikan para Rasul, menghalalkan perkara yang haram berdasarkan ijma'. Contoh perbuatan yang menjadikan pelakunya kafir adalah, melemparkan mushaf atau kitab hadis keatas kotoran, bersujud kepada arca, patung atau matahari. (Syafi'i, Juz 4: 385$)$.

Menurut Muhammad Abduh murtad adalah keluarnya seseorang dari tiga dasar yang sangat fundamental yaitu: keluar dari keyakinan bahwa alam ini diatur oleh satu Tuhan, keluar dari keimanan kepada alam ghaib dan kehidupan dunia akhirat, serta keluar dari amal saleh yang bermanfaat bagi diri manusia dan masyarakat (Abduh, Juz II, 318).

Dari defenisi-defenisi yang dikemukakan di atas, dapatlah dipahami bahwa orang yang murtad 
adalah orang yang keluar dari agama Islam dan kembali kepada kekafiran.

\section{Kriteria Riddah/Murtad}

Adapun terkait kriteria sebagai orang yang sah melakukan perbuatan riddah, Muhammad Rawas Qal'ahji berpendapat bahwa seseorang tidak dianggap murtad, kecuali orang tersebut mempunyai beberapa syarat. diantaranya sebagai berikut:

Pertama: Islam yaitu, disyaratkan bagi orang murtad adalah orang yang sebelumnya sudah memeluk agama Islam, kemudian ia meninggalkan Islam dan pindah ke agama selain Islam. Oleh karena itu, hukuman riddah tidak berlaku pada orang Yahudi yang meninggalkan agamanya pindah ke agama kristen atau sebaliknya. Tindakan itu dilakukannya dalam beragama Islam. Pindahnya non muslim dari satu agama ke agama lain, tidak disebut murtad, karena kekafiran itu sama tingkatannya antara satu dengan lainnya.

Kedua: Baligh dan berakal. Apabila orang gila, orang tidur, pemabuk dan semacamnya berucap riddah, maka tidak dianggap murtad, karena mereka berucap tidak menggunakan akalnya yang sempurna.

Ketiga: Berniat dan Ikhtiyar (القصد (و الإختيار). Tindakan riddah itu dilakukan secara sadar dengan kehendak sendiri. Apabila tindakan seorang muslim, karena terpaksa mengucapkan kalimat kufur, maka ia tidak dianggap kafir (Qal'ahjiy, 2000, Jil 1: 946).

Sayyid Sabiq dalam Fiqh alSunnah memberikan kriteria lain yang menyebabkan seseorang menjadi murtad, adalah: (a) Mengingkari persoalan-persoalan agama yang dimaklumi secara aksiomatik, seperti mengingkari keesaan Allah dan alam sebagai ciptaan-Nya. Memperbolehkan sesuatu yang telah disepakati seluruh kaum Muslimin sebagai perkara haram, seperti menghalalkan arak dan zina. (c) Mencaci maki atau meremehkan Rasulullah saw, demikian halnya dengan mencaci Nabi-Nabi Allah yang lain. (d) Mencaci maki agama, alQur'an dan hadis, tidak melaksanakan ketentuan keduanya dan menganggap undang-undang ciptaan manusia lebih unggul daripada al-Qur'an dan hadis. (e) Mengaku mendapat wahyu, (f) Membuang mushaf di tempat kotoran, 
menghina dan menganggap remeh dalam kegelapan. Cordoba kini yaitu terhadap kandungannya, dan kota Kurdu yang terletak di lembah Kedelapan, meremehkan nama dari sungai besar dan lambat laun menjadi nama-nama Allah, perintah dan kota kecil. Sedikit demi sedikit sekitar larangan-Nya (Sabiq, Jil III, 1983: 86 kota kecil yang didiami muslim 227).

\section{Al-Qurthubi dan Tafsirnya} semakin berkurang, jumlah harta simpanan desa pun semakin hilang.

Nama lengkapnya yaitu al-Imam Abu Abdillah Muhammad bin Ahmad bin Abu Bakar bin Farh al-Anshoriy alKhazrajiy al-Andalusiy al-Qurthubi alMufassir. Al-Qurthubi sendiri merupakan nama suatu daerah di Andalusia (sekarang Spanyol), yaitu Cordoba, yang dinisbahkan kepada alImam Abu Abdillah Muhammad, tempat dimana beliau dilahirkan. Tidak ada keterangan yang jelas mengenai kapan beliau dilahirkan, namun yang jelas al-Qurthubi hidup ketika Spanyol berada di bawah kekuasaan Dinasti Muwahhidun yang berpusat di Afrika Barat dan Bani Ahmar di Granada (1232-1492 M) yaitu sekitar abad ke-7 hijriyah atau 13 Masehi (Dzahabi, 2005: 401).

Al-Qurthubi hidup dan tinggal di Cordoba berada pada abad-abad akhir kegemilangan umat Islam di Eropa dan keadaan Barat yang masih tenggelam Sedikitnya terdapat 200 ribu rumah, 600 masjid, 50 rumah sakit, 80 sekolah umum yang besar, 900 pemandian. Sekitar 600 ribu kitab lebih yang kemudian dikuasai oleh Nasrani pada tahun 1236 M. Bangsa Arab menguasai Cordoba pada tahun $711 \mathrm{M}$, hingga pada puncaknya pada periode Bani Umayyah tahun $856 \mathrm{H} / 1031$ yang mengangkat dan memajukan negaranegara Eropa. Al-Qurthubi memiliki semangat yang kuat dalam menuntut ilmu. Hal ini dapat dilihat ketika Perancis menguasai Cordoba pada tahun $633 \mathrm{H} / 1234 \mathrm{M}$, beliau pergi meninggalkan Cordoba untuk mencari ilmu ke negeri-negeri lain di wilayah Timur. Beliau kemudian rihlah thalabul ilmu menulis dan belajar dengan para ulama yang ada di Mesir, Iskandariyah, Mansurah, al-Fayyun, Kairo, dan wilayah-wilayah lainnya, hingga beliau wafat pada malam senin tanggal 9 Syawal tahun $671 \mathrm{H} / 1272 \mathrm{M}$ 
dan dimakamkan di Munyaa kota Bani Khausab, daerah Mesir Utara (Dzahabi, 2005: 403).

Peran para guru serta para ulama dan syaikh sangat mempengaruhi perkembangan intelektualitas alQurthubi. Adapun nama-nama syaikh al-Qurthubi di Cordoba, diantaranya: Guru pertama Al-Qurthubi yaitu Abu Ja'far Ahmad bin Muhammad bin Muhammad al-Qaisi (atau dikenal dengan Ibn Abi Hijah), seorang alMuqri dan ahli nahwu (w. $643 \mathrm{H}$ ); AlQadhi Abu Amir Yahya bin „Amir bin Ahmad bin Muni', Yahya bin Abdurrahman bin Ahmad bin Abdurrahman bin Rabi', Abu Sulaiman Rabi' bin al-Rahman bin Ahmad alSy'ari al-Qurtubi, seorang hakim di Andalusia (w. 632 H), Abu Amir Yahya bin Abd al-Rahman bin Ahmad al-Asy'ari, seorang ahli hadis, fikih, dan teolog (w. 639 H); Abu Hasan Ali bin Abdullah bin Muhammad bin Yusuf al-Anshari Al-Qurthubi alMaliki, seorang hakim (w. $651 \mathrm{H}$ ); Abu Muhammad Abdullah bin Sulaiman bin Daud bin Hautillah al-Anshari alAndalusia, seorang ahli hadis di Andalusia, penyair dan ahli nahwu (w. 612 H) (al-Qurthubi, 2005: 16).
Kecintaan al-Qurthubi terhadap ilmu membentuk pribadi yang shalih, zuhud, arif, dan banyak menyibukkan diri untuk kepentingan akhirat. Sosok al-Qurthubi dikenal oleh para ulama sebagai ulama dari kalangan Maliki, juga seorang fikih, ahli hadis, dan sebagainya. Hal ini dikarenakan beliau banyak meninggalkan karya-karya besar yang sangat bermanfaat meliputi berbagai bidang, seperti tafsir, hadis, qira'at, dan lain sebagainya. Diantara kitab beliau yang terkenal, sebagai berikut:

Al-Jami' li al-Ahkam al-Qur'an wa al-Mubin lima Tadhammanhu min alSunnah wa al-Furqan. Merupakan kitab tafsir yang bercorak fikih. Kitab ini pertama kali dicetak di Kairo pada tahun 1933-1950 M oleh Dar al-Kutub al-Mishriah sebanyak 20 jilid. Setelah itu pada 2006 penerbit Mu'assisah alRisalah Beirut, mencetak sebanyak 24 juz/jilid yang telah di-tahqiq oleh Abdullah bin Muhsin al-Turki.

Al-Tadzkirah fi Ahwa l al-Mauti wa Umur al-Akhirah, diterjemahkan kedalam bahasa Indonesia sebagai "Buku Pintar Alam Akhirat" yang diterbitkan di Jakarta tahun 2004, Kitab Al-Tidzkar fi Fadli al-Azkar, yang 
berisi tentang penjelasan kemuliaankemuliaan al-Qur'an, dicetak pada tahun 1355 M di Kairo.

Kemudian kitab Qama al-Hars bi al-Zuhdi wa al-Qana'ah wa Radd zil al-Sual bi al-Katbi wa al-Syafa'ah. Dicetak oleh Maktabah al-Sahabah Bitanta pada tahun 1408, Al-Intihaz fi Qira'at Ahl al-Kuffah wa al-Bashrah wa al-Syam wa Ahl al-Jijaz, Al-I'lam bima fi Din al-Nashara min al-Mafasid wa Awham wa Kazhar Mahasin alIslam. Dicetak di Mesir oleh Dar alTurats al-Arabi, Al-asna fi Syarh Asma al-Husna wa Sifatuhu fi al-Ulya, AlI'lam fi Ma'rifati Maulid al-Musthafa 'alaih al-Shalat wa al-Salam, terdapat di Maktabah Tub Qabi, Istanbul, Urjuzah fi Asma al-Nabi SAW. Kitab ini disebutkan dalam kitab al-Dibaj alZahab karya Ibn Farh (al-Dzahabi, 2005: 401).

Tafsir Jami'I Li Ahkam al-Qur'an, merupakan salah satu karya besar alQurthubi dalam bidang tafsir. Kitab tafsir ini masyhur disebut tafsir alQurthubi, karena tafsir ini merupakan karya dari seorang yang mempunyai nisbah nama al-Qurthubi. Pada halaman sampul kitabnya juga tertulis judul Tafsir al-Qurthubi al-Jami'i li
Ahkam al-Qur'an. Jadi tidak dipungkiri apabila seseorang menyebut tafsir ini dengan sebutan Tafsir al-Qurthubi. Judul lengkap kitab tafsir ini adalah $\mathrm{Al}$ Jami'i lil Ahkam al-Qur"an wa alMubin Lima Tadammanhu min alSunnah wa ai al-Furqan, yang berarti kitab ini berisi himpunan hukumhukum al-Qur'an dan penjelasan terhadap isi kandungannya dari alSunnah dan ayat-ayat al-Qur'an.

Latar belakang mengapa alQurthubi menyusun kitab tafsir ini adalah semata-mata karena dorongan hatinya, bukan atas permintaan seorang tokoh ataupun mimpi. Hal ini beliau curahkan pada bagian pendahuluan kitab tafsirnya. Berdasarkan kategorisasi metode tafsir maka dapat dikatakan bahwa tafsir al-Qurthubi menggunakan metode tahlili. Hal ini dapat dilihat dari cara al-Qurthubi dalam menjelaskan kandungan ayat secara panjang lebar dan mendalam dari berbagai aspek secara runtut dengan langkah-langkah penafsiran sesuai dengan metode tafsir tahlili. Berikut langkah-langkah penafsiran alQurthubi: (a) Menyebutkan ayat, (b) Menyebutkan poin-poin masalah ayat yang dibahas ke dalam beberapa 
bagian, (c) Memberikan kupasan dari segi bahasa, (d) Menyebutkan ayat-ayat lain yang berkaitan dan hadis-hadis dengan menyebut sumber dalilnya, (e) mengutip pendapat ulama dengan menyebut sumbernya sebagai alat untuk menjelaskan hukum-hukum yang berkaitan dengan pokok bahasan, (f) Menolak pendapat yang dianggap tidak sesuai ajaran Islam, dan (g) Mendiskusikan pendapat ulama dengan argumentasi masing-masing dan mengambil pendapat yang paling benar (al-Qurthubi, Jil 1, 2005: 16).

Al-Qurthubi memang terkenal beraliran fikih al-Maliki, namun dalam menentukan hukum-hukum fikihnya, ia tidak fanatik dengan mazhabnya. Bahkan al-Qurthubi sebenarnya ketika memaparkan atau menjelaskan hukum itu banyak menyertakan dalil-dalil, dan analisis (al-Qurthubi, Jil 1, 2005: 16).

\section{Pemahaman Al-Qurthubi terhadap Makna Riddah}

\section{Makna Riddah dalam al-Qur'an}

Makna riddah dalam al-Qur'an terdapat dalam beberapa surah, diantaranya QS. al-Maidah 54 dan QS. Muhammad 25. Pertama, penjelasan makna riddah terdapat di dalam QS. alMaidah 54.

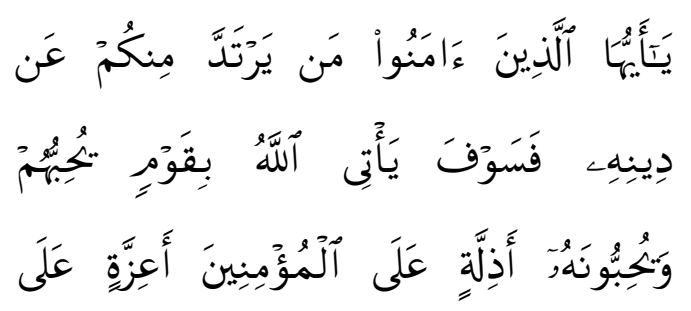

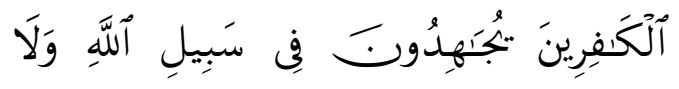

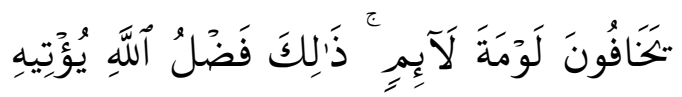

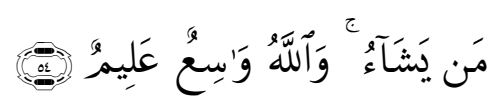

"Hai orang-orang yang beriman, Barangsiapa di antara kamu yang murtad dari agamanya, Maka kelak Allah akan mendatangkan suatu kaum yang Allah mencintai mereka dan merekapun mencintaiNya, yang bersikap lemah lembut terhadap orang yang mukmin, yang bersikap keras terhadap orang-orang kafir, yang berjihad dijalan Allah, dan yang tidak takut kepada celaan orang yang suka mencela. Itulah karunia Allah, diberikan-Nya kepada siapa yang dikehendaki-Nya, dan Allah Maha Luas (pemberian-Nya), lagi Maha mengetahui. '(QS. al-Maidah [5]: 54)

Menurut al-Qurthubi makna

murtad dalam ayat مَنْ يَرْنَدَّ مِنْكُمْ عَنْ دِيْنِهِ terbagi dua, yaitu meninggalkan dan keluar dari syari'at Islam, kemudian meninggalkan dan menentang kewajiban zakat. Al-Qurthubi menjelaskan, ayat ini kolerasi dengan ayat sebelumnya. Pada ayat sebelumnya Allah melarang umat Islam 
menjadikan orang-orang Yahudi dan Nashrani sebagai awliya', maka pada ayat ini Allah menegaskan bahwa sekiranya larangan itu dilanggar maka pelakunya akan terjatuh pada kemurtadan (al-Qurthubi, Jil VIII, 2006: 51).

\section{Faktor Penyebab Riddah}

Di antara penyebab riddah itu adalah:

Dimurtadkan Oleh Orang-Orang Kafir

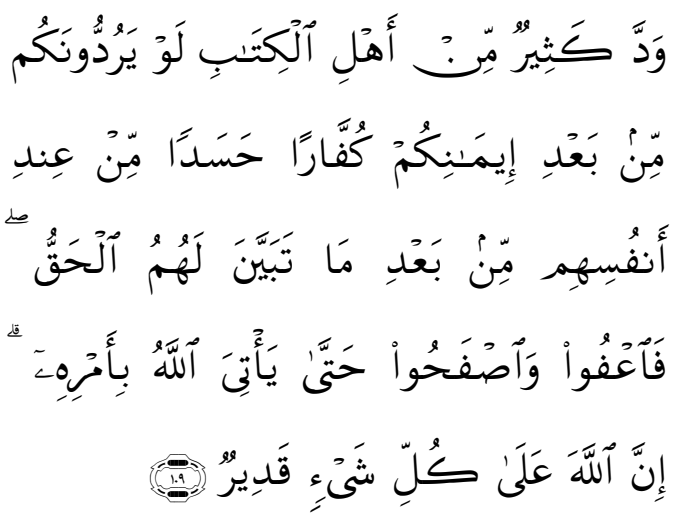

"Sebahagian besar ahli kitab menginginkan agar mereka dapat mengembalikan kamu kepada kekafiran setelah kamu beriman, karena dengki yang (timbul) dari diri mereka sendiri, setelah nyata bagi mereka kebenaran. Maka ma'afkanlah dan biarkanlah mereka, sampai Allah mendatangkan perintah-Nya. Sesungguhnya Allah Maha Kuasa atas segala sesuatu." (QS. al-Baqarah [2]: 109)

Menurut al-Qurthubi, maksud ayat وَدَّ كَثْيْرُ مِنْ آَهْلِ الكِكَّاب kitab terdahulu yang berusaha mengembalikan keimanan menjadi kafir setelah mengetahui kebenarannya.
Salah satu sebab perbuatan orang yang memurtadkan itu karena mempunyai sifat dengki di dalam hatinya (kepada muslim). Hasad حَسَدًا yang dimaksud oleh ayat di atas sebagai illah dari sifatsifat orang murtad yang berusaha mengembalikan keimananan menjadi kafir. Maka ayat di atas menjadi salah satu penyebab dari pelaku riddah yaitu dimurtadkan oleh orang-orang kafir itu sendiri. Orang murtad yang dimaksud adalah ahli kitab dari Yahudi dan Nasrani, yang memiliki sifat dengki dalam hatinya terhadap orang Islam (al-Qurthubi, jil II, 2006: 313).

Menjadikan Orang Kafir Sebagai Teman

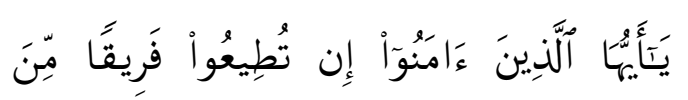

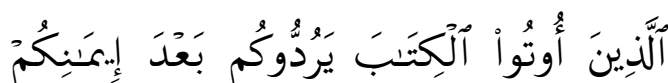

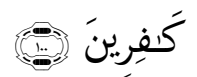

"Hai orang-orang yang beriman, jika kamu mengikuti sebahagian dari orang-orang yang diberi Al Kitab, niscaya mereka akan mengembalikan kamu menjadi orang kafir sesudah kamu beriman."(QS Ali-Imran [3]: 100)

Menurut al-Qurthubi, ayat ini turun berkenaan dengan pertikaian antara kabilah 'Aus dan Khazraj. Dua suku ini saling bersengketa dan bentrok, sebagian orang Yahudi 
memandang persatuan ini merugikan dan mereka merancang strategi untuk mengobarkan api perpecahan supaya Muslimin kembali bermusuhan. Oleh karenanya, salah satu dari kelompok tersebut mengingatkan kembali luka masa silam saat perang antara kabilah. Perbuatan tersebut hampir saja terjadi perang besar-besaran, sehingga turunlah ayat ini. Maka dalam hal ini, seseorang yang berteman dan bergaul dengan orang-orang kafir bisa mengembalikannya kepada kekafiran (al-Qurthubi, jil V, 2006: 234).

Al-Qurthubi dalam menjelaskan asbabun nuzul ayat ini mempunyai pendapat yang sama, bahwa pada zaman Jahiliyah terjadi pertikaian antara 'Aus dan Khazraj. Ibnu Ishaq dan Abu Asy-Syaikh meriwayatkan dari Zaid bin Aslam, ia berkata, "Syas bin Qais, dia adalah seorang Yahudi yang melewati sekelompok orangorang 'Aus dan Khazraj. Dia melihat dari sekelompok orang 'Aus dan Khazraj sedang bercakap-cakap, hingga diapun marah melihat keserasian mereka setelah permusuhan. Lantas dia memerintahkan seorang pemuda Yahudi untuk menjadi provokator dalam mengingatkan peristiwa yang terjadi pada perang Bu'ats, agar mereka saling berselisih, membangga banggakan diri. saling berdebat dan kedua kelompok menjadi marah serta saling melompat untuk berperang. Mereka adalah 'Aus bin Khaizi dari 'Aus dan Jabbar bin Sakhar dari Khazraj. Sehingga, berita ini sampai kepada Rasulullah SAW. lalu beliau datang untuk memberi nasehat serta memperbaiki kaadaan di antara mereka (al-Qurthubi, jil V, 2006: 234).

Dalam ayat lain Allah swt berfirman:

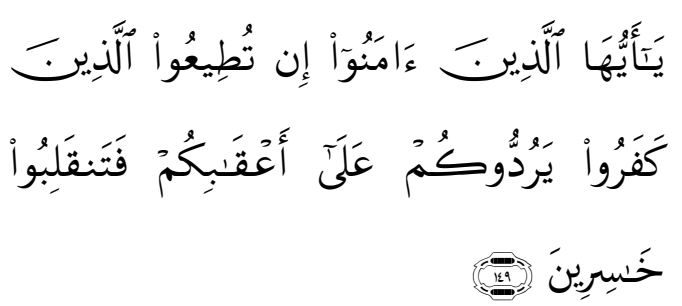

"Hai orang-orang yang beriman, jika kamu mentaati orang-orang yang kafir itu, niscaya mereka mengembalikan kamu ke belakang (kepada kekafiran), lalu jadilah kamu orang-orang yang rugi. '(QS Ali-Imran [3]: 149)

Menurut al-Qurthubi, yang dimaksud dengan ayat di atas adalah perintah untuk mengikuti orang-orang yang terdahulu dari kaum Anshar, agar tidak berpaling mentaati orang kafir (Musyrik Arab) seperti Abu Sufyan dan para sahabatnya. Satu pendapat mengatakan mereka adalah orang- 
orang Yahudi dan Nasrani. Dalam

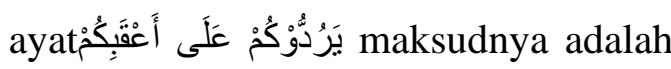
perbuatan mengembalikan seseorang menjadi kafir. Salah satu dampaknya mendapat kehinaan baik di dunia maupun di akhirat dan menjadi orang yang merugi (al-Qurthubi, jil V, 2006: $355)$.

\section{Hukuman Bagi Orang Murtad Menurut al-Qurthubi}

\section{Hukuman Bunuh}

Menurut al-Qurthubi, hukuman bagi orang murtad adalah dibunuh. Bَ

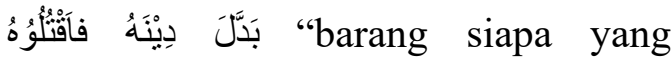
menukar agamanya maka dibunuh". Namun, dalam hal ini al-Qurthubi menjelaskan bahwa orang murtad dituntut taubat sebelum dibunuh baik ia laki-laki maupun perempuan (alQurthubi, jil III, 2006: 428).

Sia-sia Amal di Dunia dan di Akhirat

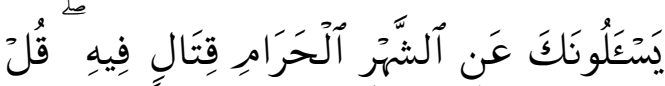

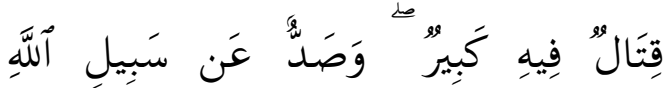

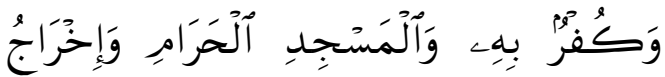

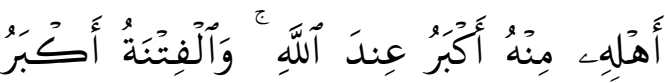

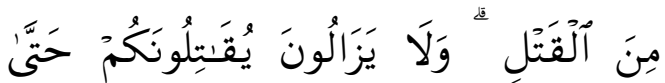

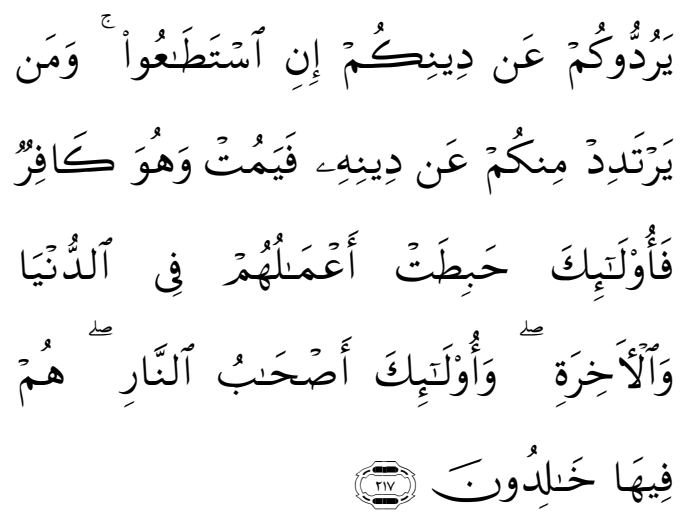

"Mereka bertanya kepadamu tentang berperang pada bulan Haram. Katakanlah: "Berperang dalam bulan itu adalah dosa besar, tetapi menghalangi (manusia) dari jalan Allah, kafir kepada Allah, (menghalangi masuk) Masjidilharam dan mengusir penduduknya dari sekitarnya, lebih besar (dosanya) di sisi Allah. dan berbuat fitnah lebih besar (dosanya) daripada membunuh. mereka tidak henti-hentinya memerangi kamu sampai mereka (dapat) mengembalikan kamu dari agamamu (kepada kekafiran), seandainya mereka sanggup. Barangsiapa yang murtad di antara kamu dari agamanya, lalu Dia mati dalam kekafiran, Maka mereka Itulah yang sia-sia amalannya di dunia dan di akhirat, dan mereka Itulah penghuni neraka, mereka kekal di dalamnya." (QS al-Baqarah [2]: 217

Mَ maksudnya adalah seseorang yang kembali dari Islam kepada kekafiran, yang sia-sia (terhapus) amalannya di dunia dan di akhirat. Ayat ini merupakan peringatan bagi kaum Muslimin untuk selalu tetap dalam

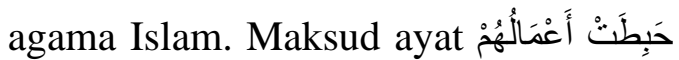


"terhapus amalan" jika dia mati dalam keadaan kafir, tetapi jika orang murtad itu kembali lagi kepada Islam, amalannya tidak terhapus. Imam Malik juga mengatakan makna murtad tersebut adalah orang yang keluar dari Islam kepada kafir, tidak termasuk orang yang kafir kembali kepada kafir, karena ini tidak berarti (al-Qurthubi, jil III, 2006: 428).

\section{Relevansi Riddah dalam Penafsiran al-Qurthubi dengan Indonesia}

\section{Riddah Dalam Konteks Keindonesiaan}

Perbuatan riddah (murtad) di

Indonesia dikenal dengan perpindahan dari suatu agama ke agama lain. Dalam konteks negara Muslim yang pluralis seperti Indonesia, riddah pada hakikatnya menjadi bagian dari kebebasan hak asasi manusia untuk menentukan pilihannya yang dilindungi undang-undang, berbeda dengan riddah yang masuk dalam kategori jinayah alasasiyah atau terindikasi kemurtadannya itu diiringi dengan tindakan makar untuk menggulingkan pemerintahan, pemberontakan atau subversi. Pasal 18-19 Deklarasi Hak Asasi Manusia memberikan jaminan atas kebebasan berpikir, kebebasan hati nurani, kebebasan agama, kebebasan pendapat dan menyatakan perasaan, termasuk juga kebebasan untuk berpindah agama dan mewujudkan dalam pengajaran, pengamalan dan peribadatan. Dalam pandangan Islam, baik perspektif histories maupun konseptual menegaskan bahwa kebebasan manusia terjamin sepenuhnya, terutama kebebasan memilih dan memeluk agama (Syafe'I, 2016: 10).

Dalam hukum Islam, perbuatan riddah termasuk dalam kategori jarimah yang dalam hukum positif disebut tindak pidana. Berbeda dengan kebebasan beragama yang ia berada di bawah naungan Undang-Undang Dasar, kebebasan beragama dalam pengertian hukum Islam tidak berarti bebas untuk berpindah agama mengingat bahwa terdapat aturanaturan baku perihal perihal pindah agama. Dengan demikian, kebebasan beragama menjadi polemik tersendiri dalam menerapkan konsekuensi hukum yang berlaku. Dalam terminologi hukum positif, suatu tindak pidana memberikan suatu konsekuensi hukuman bagi pelaku kejahatan. Perkataan pidana sendiri berasal dari 
bahasa sansekerta yang berarti Al-Sayyid al-Sabiq menjelaskan hukuman. Dari pengertian tersebut, bahwa riddah adalah kembalinya orang terlihat bahwa yang dimaksud dengan Islam yang berakal dan dewasa pada tindak pidana adalah suatu perbuatan kekafiran dengan kehendaknya sendiri melawan hukum, baik berupa tanpa ada paksaan dari orang lain, baik pelanggaran terhadap larangan, ia laki-laki atau pun perempuan. maupun pengabaian terhadap Bahkan secara spesifik, riddah sering kewajiban, yang diancam dengan diartikan dengan keluar dari Islam hukuman berdasarkan Undang- menjadi non-Muslim, tidak sebaliknya. Undang. Namun demikian, perilaku Alasannya, perpindahan dari orang riddah dan kebebasan beragama kafir ke agama yang juga kafir itu tidak memiliki keterkaitan dan hubungan ada perbedaan karena sama-sama batil. antara yang satu dengan lainnya Sedangkan perpindahan Muslim pada (Rohman, Tesis: 2015).

Dalam ensiklopedi Islam agama kafir berarti perpindahan dari Indonesia, riddah makna aslinya adalah kembali kejalan semula. Namun demikian, istilah ini dalam agama yang benar pada kesesatan dan kekafiran (Sabiq, Juz III, 1977: 98).

Dalam pandangan al-Qurthubi penggunaannya lebih banyak dari syari'at Islam, kemudian kembali dikhususkan untuk pengertian kembali atau keluarnya seseorang dari agama Islam kepada kekufuran atau pindah dari agama Islam kepada agama lain. Dari pengertian riddah ini dapat dikemukakan tentang pengertian murtad, yaitu orang Islam yang keluar dari agama Islam yang dianutnya kemudian pindah memeluk agama lain atau sama sekali tidak beragama (Nasution, 1992: 696).

kepada kafir.

\section{Faktor Riddah di Indonesia}

Menurut Zakiah Daradjat dalam karyanya Ilmu Jiwa Agama, ada beberapa faktor yang menyebabkan perpindahan agama, antara lain: (1) Pertentangan batin (konflik jiwa) dan ketegangan perasaan (2) Pengaruh hubungan dengan tradisi agama (3) Ajakan atau seruan dan sugesti (Daradjat, 2005: 184). 
Dalam sebuah artikel dijelaskan bahwa diantara faktor perbuatan pindah agama (murtad) di Indonesia adalah pindah agama karena menikah, kemiskinan, rasa takut yang muncul menjelang ajal, takut tidak masuk surga, menemukan rasa nyaman setelah kecewaan, doa yang tidak dikabulkan, tertarik dengan sejarah agama tertentu, karena asuhan nenek buyut, dan rasa penasaran (Artikel Mojok, 2019).

Dalam penafsiran ulama klasik, bahwa Allah tidak memberikan ancaman duniawi bagi siapa pun yang memeluk agama sesuai dengan kepercayaannya, apakah dia memeluk agama Islam atau selain Islam. Begitu pula berpindah agama dari Islam kepada agama lainnya atau sebaliknya. Semua orang memiliki kebebasan untuk memegang keyakinan masingmasing, tanpa harus dipaksakan dan tanpa harus memaksa orang lain. Oleh sebab itu, bila seseorang pada awalnya memeluk satu agama kemudian berpindah kepada agama lainnya (riddah) baik dari Islam kepada non Islam atau sebaliknya, maka perlu dicarikan alasannya jika dipandang sebagai tindak kriminal yang harus mendapatkan sanksi hukum, lebih-lebih bila hukuman itu berupa hukuman mati. (Syafe'I, 2016: 6).

Islam memandang seseorang yang melakukan riddah dari kesetiaan terhadap Islam adalah perbuatan dosa tak terampunkan. Mereka dianggap menjauh dari Allah sebagai pemiliknya dan dapat melemahkan negara, karena tindakan tersebut dapat dikatagorikan sebagai pemberontakan atau pengacauan. Mereka itu patut dihukum, dipaksa untuk kembali ke Islam dan bertobat. Jika diperlukan proses kembali ke Islam dilakukan dengan kekerasan dan siksaan. Mereka yang tidak memeluk Islam lagi diakhiri hidupnya dengan hukuman mati oleh Negara (Syafe'I, 2016: 6).

Sebab-sebab terjadinya Riddah dalam perspektif pandangan Islam, diantaranya yaitu: (Artikel Zain, 2013).

Pertama, Karena kebodohan

Kebodohan menjadi penyebab utama adanya gelombang pemurtadan, karena mereka tidak dibentengi dengan ilmu. Oleh karena itu salah satu cara yang efektif untuk mengantisipasi pemurtadan adalah dengan menyebarkan aqidah dan ilmu yang benar di kalangan masyarakat.

Kedua, Kemiskinan 
Pemurtadan seringkali terjadi pada daerah-daerah miskin dan terkena bencana. Banyak kaum muslimin yang mengorbankan keyakinan mereka hanya untuk sesuap nasi dan sebungkus Supermi.

Ketiga: Tidak pemerintahan Islam

Hilangnya pemerintahan Islam yang menegakkan syariat Allah membuat musuh-musuh Islam leluasa melakukan pemurtadan dan penyesatan terhadap umat Islam. Begitu juga umat Islam tidak akan berani main-main dengan agamanya. Berikut ini beberapa bukti bahwa pemerintahan Islam mempunyai peran penting di dalam menghentikan gelombang pemurtadan. Para Khulafa' Rasyidin menegakkan memerangi orang-orang yang murtad dan menghukumi mereka dengan hukuman mati, seperti yang dilakukan oleh Abu Bakar Siddiq terhadap Musailamah al-Kadzab dan para pengikutnya.

\section{Keempat: Adanya dorongan}

Munculnya pemikiran-pemikiran sesat seperti liberalisme, pluralisme dan sekulerisme telah mendorong terjadi gelombang kemurtadan di kalangan kaum muslimin, karena paham-paham tersebut mengajarkan bahwa semua agama sama, dan semua orang bebas melakukan perbuatan apapun juga, tanpa takut dosa.

Dalam pandangan al-Qurthubi sebab terjadinya riddah dimurtadkan oleh orang-orang kafir, karena sering mengikuti langkah-langkahnya dan menjadikan orang kafir sebagai teman.

\section{Hukuman Riddah di Indonesia}

Transformasi penerapan hukum Islam di Indonesia terus bergulir dari sejak republic ini berdiri. Bukan saja hanya pada bidang hukum keluarga tetapi berbagai hukum lainnya, meski belum sepenuhnya sistem hukum Islam di Indonesia ini mengacu kepada hukum-hukum Islam. Tetapi, proses ke arah pengembangan hukum Islam untuk menjadi bagian dari sistem hukum nasional patut disyukuri, meskipun tidak mesti proses pengembangan hukum Islam akan tertuju pada pembentukan negara agama. Karena yang dibutuhkan bukan dalam bentuk normalisasi Negara Islam, melainkan bagaimana nilai-nilai dan moral Islam menjadi materi dan sistem hukum yang berlaku di Negara Indonesia ini yang mana negaranya mayoritas Muslim. Salah satu aspek 
yang terkait dengan hukum publik dan patut menjadi pertimbangan dalam perumusan hukum nasional adalah tindakan riddah atau perpindahan dari satu agama kepada agama yang lainnya (murtad) yang selama ini tidak di muat dalam KUHP (Pradana, 2005: 135).

Indonesia bukanlah Negara agama meskipun mengayomi penganut umat beragama, di samping warga negaranya multikultural dan pluralis, nampaknya untuk menformalkan hukum Islam yang mengikat bagi seluruh warga negara akan mengalami hambatan yang serius. Hal ini bukan berarti peluang tidak ada, namun dampak yang akan timbul karenanya, patut menjadi perhitungan dan kalkulasi politik bagi keutuhan Negara Kesatuan Republik Indonesia (NKRI).

Untuk mengimplementasikan semua itu tidak harus mengubah Negara Kesatuan Republik Indonesia menjadi Negara Islam, namun yang terpenting adalah hukum Islam harus dapat menjiwai dan menjadi pondasi utama bagi struktur hukum nasional. Oleh karena itu, hukum Islam dapat berperan sebagai pondasi utama dan melengkapi kekurangan-kekurangan hukum nasional.
Relevansi murtad dalam konteks NKRI, maka hukuman bunuh bagi orang murtad tidak dikenal dalam hukum positif yang berlaku di negara kita. Hukuman bunuh bagi orang murtad, masuk dalam ketentuan hukum Islam maka penetapan hukum bunuh untuk orang murtad, hanya bisa dilakukan dan diputuskan oleh pengadilan Syariat yang resmi ditunjuk oleh pemerintah (jika negara kita menerapkan hukum Islam). Oleh karena itu, bagi negara yang tidak menerapkan hukum Islam sebagai konstitusi resmi negaranya, termasuk Indonesia, orang murtad itu sanksinya diserahkan kepada Allah, tidak ada sanksi duniawi atasnya (Mutawali, Jurnal: 2017).

Dalam penafsiran al-Qurthubi, hukuman bagi orang murtad adalah dibunuh. Hal ini berdasarkan sabda مَنْ بَدَّلَ دِيْنَهُ فَاقَتْلُوُُهُ Rasulullah SAW "barang siapa yang menukar agamanya maka dibunuh". Namun, orang murtad tersebut dituntut taubat terlebih dahulu sebelum dibunuh baik ia laki-laki maupun perempuan dan amalnya terhapus baik di dunia dan di akhirat. 


\section{KESIMPULAN}

Hasil penelitian ini menyimpulkan bahwa ketentuan riddah dalam alQur'an menurut al-Qurthubi cukup jelas dan tegas. Hal itu bisa dilihat pada aspek-aspek berikut:

Pertama: Menurut al-Qurthubi makna riddah adalah meninggalkan keimanan dan kembali menjadi kafir atau suatu yang mengarah kepada kekufuran, seperti memperolok-olok agama, melawan ketentuan atau menolak keabsahan dalil yang disepakati dan lain-lain. Kedua: Sebab perbuatan riddah menurut al-Qurthubi adalah dimurtadkan oleh orang-orang kafir dengan sebab dengki, saling berteman dan bergaul dengannya. Ketiga: Hukuman bagi orang murtad menurut al-Qurthubi adalah dibunuh dengan tuntut taubat dan terhapus amalan di dunia dan di akhirat.

Relevansi penafsiran al-Qurthubi dengan zaman sekarang cukup urgen, namun segi hukuman terhadap orang murtad terlihat bertentangan dengan zaman sekarang. Di Indonesia hukuman bunuh tidak bisa diterapkan, karena hak asasi manusia (HAM) selalu dijadikan sebagai rujukan kebebasan dalam berpindah agama.
Maka pelaku riddah hanya bisa dilakukan dan diputuskan oleh pengadilan Syari`at yang resmi ditunjuk oleh pemerintah (jika negara kita menerapkan hukum Islam). Negara yang tidak menerapkan hukum Islam sebagai konstitusi resmi negaranya, termasuk Indonesia, maka terhapus atau sia-sia amalan orang murtad sanksinya diserahkan kepada Allah, tidak ada sanksi duniawi atasnya.

\section{REFERENSI}

Abdurrahman. A. 1996. QaidahQaidah Fiqih (Jakarta: Bulan bintang)

Abu Bakar, 2015. TOLERANSI: Media Komunikasi Umat Bergama, (Vol.7, No.2 JuliDesember 2015)

Alim. M. 2001. Demokrasi dan Hak Asasi Manusia Dalam Konstitusi Madinah dan UUD 1945, Cet.1, (Yogyakarta: UII Press)

Abdullah, 2018. Kajian Kitab Tafsir "al-Jami' li ahkam al-Qur'an" Karya: Al-Qurthubi, Jurnal Kewahyuan Islam.

al-Baqi, M.F.A. 1981. Mu"jam AlMufahras li Alfaz Alquran AlKarim. (Beirut: Dar Al-Fikr)

Baidan, N. 1988. Metode penafsiran alQur'an (Jakarta: Pustaka Belajar)

Basuki. S. 2013 KEBEBASAN BERAGAMA DALAM MASYARAKAT (Studi Tentang Pindah Agama dan Konsekuensinya Menurut Pemikir Muslim Kontemporer) 
Religi, Vol. IX, No. 1, Januari 2013: 59-79

Bustamam, R. 2018. Hakikat AlQur'an (Pendekatan Qur'an dengan Pendekatan Tafsir Tematik) Jakarta: Prenadamedia Group (Devisi Kencana).

Buchori.

D.S.2005. Pedoman

Memahami Kandungan alQur'an. Granada Sarana

Cahyono. 2015. Studi Pemikiran Jamal

Al-Bana Tentang Konsep

Murtad Dalam Pidana Islam.

Skripsi, Universitas Islam

Negeri Walisongo Semarang.

Amril, D., \& Hafizzullah, H. (2020). KONSEP MAKAR DAN CARA MENGATASINYA DALAM PERSPEKTIF AL QUR'AN. Al FAWATIH: Jurnal Kajian Al Quran dan Hadis, 1(1), 31-46.

Damanik, N. Toleransi Dalam Islam. Shahih: Jurnal Ilmu Kewahyuan th.2019

Daradjat, D. 2005. Ilmu Jiwa Agama, (Jakarta: Bulan Bintang)

al-Dzahabi, M. H. 2005. Al-Tafsir Wal Mufassirin Jilid 2 (Kairo: Darul Hadis)

al-Farmawi, A.H. 1977. Muqaddimah fi al-Tafsir al-Mawdhu"i. AlHadharah al-'Arabiyah. Kairo.

Ghofur, S.A. 2008. Profil Para Mufassir al-Qur"an (Yogyakarta: Pustaka Insan Madani)

Hafizzullah, H., Ismail, N., \& Ulya, R. F. (2020). Tafsir Lathâif alIsyârât Imam al-Qusyairy: Karakteristik dan Corak Penafsiran. Jurnal Fuaduna: Jurnal Kajian Keagamaan dan Kemasyarakatan, 4(2), $\quad$ 147159.
Izan, A. 2011 Metodologi Ilmu Tafsir (Cet III, Bandung: Tafakur)

al-Jaziri, A. R. 2000 al-Fiqh `ala alMadhahib al-Arba`ah, (alQahirah: al-Maktab al-Thaqafî)

Muslich, A.M. 2005 hukum pidana islam (Jakarta: Sinargrafika)

Muamar. A. Kebebasan Beragama dan Problematika HAM Universal (Vol. 11, No. 1, Maret 2013)

Muqshit, A. Tafsir atas hukum murtad dalam islam, Ahkam: Vol. XIII, No. 2, Juli 2013

al-Munzir, M.I, 1986, Al-Isyraf 'al Mazahib Ahl illmi, Qathar, Idarah Ihyae wa Turath, Cet.I. 51

Nada P.M. 2004. Riddah Dan Relevasinya Dengan Kebebasan Beragama. Skripsi IAIN Sunan Kalijaga Yogyakarta.

al-Qatthan, M. Mabahis fi 'Ulum al-

Qur'an, (Kairo: Maktabah

Wahbah, tth),

al-Qurthubi. A. M. A. 2002. Al-Jami' li Ahkam al-Qur'an, (al-Qahirah: Dar al-Hadist, Jil. II) 2002 al-Jami' Ahkam alQur'an, al-Qahirah: Dar alHadits. Jil: VIII

2005 al-Jami' li Ahkam alQur"an Jil. I, (Kairo: Maktabah al-Shafa)

2006 al-Jami' li Ahkam alQur"an Walmubayyinu Lima Tadhammanahu Mina alSunnati wayyil Furqon Jil.VIII (Beirut/Libanon: Al-Resalah Publishers)

2006 al-Jami' li Ahkam alQur"an Walmubayyinu Lima Tadhammanahu Mina alSunnati wayyil Furqon jilid XIX (Beirut/Libanon: AlResalah Publishers) 
2006 al-Jami' li Ahkam alQur"an Walmubayyinu Lima Tadhammanahu Mina alSunnati wayyil Furqon Jil. II (Beirut/Libanon: Al-Resalah Publishers) 2006 al-Jami' li Ahkam alQur"an Walmubayyinu Lima Tadhammanahu Mina alSunnati wayyil Furqon Jil.V (Beirut/Libanon: Al-Resalah Publishers)

2006 al-Jami' li Ahkam alQur"an Walmubayyinu Lima Tadhammanahu Mina alSunnati wayyil Furqon Jil.III (Beirut/Libanon: Al-Resalah Publishers)

Qal'ahji, M. R. al-Mawsu'ah alFiqhiyyah al-Muyassarah. Beirut: Dar al-Nafa'is, $1421 \mathrm{H}$ : $2000 \mathrm{M}$.

Rahayu. L. 2010 Makna Qaulan dalam al-Qur'an Tinjauan Tafsir Tematik Menurut Wahbah Az Zuhaili (Skripsi Sarjana, Fakultas Ushuluddin Universitas UIN SUSKSA Riau, Pekanbaru)

Rodin. D. Riddah dan Kebebasan Beragama Dalam al-Qur'an: Ahkam: Vol. XIV, No. 2, Juli 2014

Ridha. M.R 1990. Tafsir al-Quran alHakim (Tafsîr al-Manar), Mesir: al-Hay'ah al-Mihriyyah al-'Ammah li al-Kitab.

Rohman, A.N. Riddah Dalam Hukum Islam dan Hukum Positif di Indonesia. Tesis Universitas Muhammadiyah Jakarta tahun 2015

al-Razi, F.A. 1995. Mafatih al-Ghaib, Jil. XIV (Bairut: Dar al-Fikr).
Suma. M.A. 2001. Pengantar Tafsir Ahkam (Cet 1 Jakarta: PT Raja Grafindo Persada)

Saleh, A.S. 2007. Metodologi Tafsir alQur'an Kontemporer dalam Pandangan Fazlur Rahman. Sulthan Thaha Press. Jakarta

Sholeh. Moh. J. Tafsir al-Qurthubi: Metodologi, Kelebihan dan Kekurangannya. Jurnal Reflektika Vol.13, No.1, Januari-Juni 2018.

al-Sabiq. M.S. 1983 Fiqh al-Sunnah, Jil. II (Beirut: Dar al-Fikr) 1983 Fiqh al-Sunnah, Jil. III (Beirut: Dar al-Fikr) 1997 Fiqh al-Sunnah, (Beirut: Dar al-Fikr, Juz III)

Syukur. A. Mengenal Corak Tafsir alQur'an Vol 01. No 01. Agustus 2015

al-Shyairazi, A. I. al-Muhadhdhab fiFigh al-Imam al-Shafi i, juz II

Ulya, R. (2020). Konsep Jihad dalam Tafsir Al-Maraghi (Studi Tafsir Tematik Tentang Jihad dalam QS. At-Taubah). Ishlah: Jurnal Ilmu Ushuluddin, Adab dan Dakwah, 2(2), 274-303.

Wijayanti. 2016. Hukum Pidana Islam (Jakarta: Sinargrafika)

Zed. M. 2004 Metode Penelitian Kepustakaan. Yayasan Obor Indonesia: Jakarta

Zaini. H. dkk. 2015 Ilmu Tafsir STAIN Batusangkar Press

Zailiya. S. Murtad Dalam Perspektif Syafi'I dan Hanafi Istinbath/No.15/Th. XIV/Juni/2015/67-88 